\title{
Importance of Life Skills Training for Corporate Sector
}

\author{
Sreehari Ravindranath, R. Joseph Thomas and Asna Shareef
}

\begin{abstract}
Human resources with positive attitudes towards life and work and germane skills for advanced knowledge economy that are publicly responsible and accountable is becoming important in today's high momentum humanity. It is important that we mobilize skills such as personal management and people management skills which are necessary for adequate functioning which help us to steer our life towards more positive behavior and wellbeing. Specifically, life skills are termed as psycho social skills which empower individuals to flourish and prosper in competitive world and adapt to milieus in which we live in certain aspects such as behavioral, cognitive, social and intrapersonal. Corporate Life Skills training assists both individuals and small teams in your workplace to addressing issues affecting their work performance. This paper is conceptual papers which discuss the importance of Life skills training, which is an emerging concept in the corporate sector.
\end{abstract}

Keywords--- Life Skills Training, Corporate Training

\section{INTRODUCTION}

$\mathrm{T}$ RAINING is a process that induces behavioral changes in the areas of knowledge and competencies that are helpful in improving performance at work situations and contributing to self-development. It majorly focuses on knowledge, attitude and skill. It is also a process to empower the participants and remove mental blocks. (Agochiya, 2010)[1]

The role of training is to improve the organization's effectiveness by providing employees with the knowledge, attitude and skill that will enhance their current or future job performances. At the same time, effective training must address the personal needs of the employees, helping them to learn, to grow, and to cope with the issues that are important to them. The attitude of employees toward their organization affects the employee motivation and performance. Training itself can play role in how positively employees view the organization. (Blanchard- Thacker, 2004)[2]

Team development is another important aspect of training

Sreehari Ravindranath, Research Fellow from the school of Life Skills Education, Rajiv Gandhi National Institute of Youth Development, Chennai. E-mail:harijyothis@gmail.com

R. Joseph Thomas, Research Fellow from the school of Life Skills Education, Rajiv Gandhi National Institute of Youth Development, Chennai. E-mail: thomasjoseph8@gmail.com

Asna Shareef, Student from the school of Life Skills Education, Rajiv Gandhi National Institute of Youth Development, Chennai. E-mail: asnashareef26@gmail.com

DOI: 10.9756/BIJAIP.1387 and it is also important to note that it will increase the cohesiveness of the group and will reduce conflict. Instead of sending isolated individuals off to a sensitive training session attended by strangers, a type of sensitivity session can be conducted for the members of an operating unit, off site, away from the job. This can help in team building and creating a "we" feeling among the group members. Another important is career development of the employees through training and development. Training in corporates always creates a platform for employees to understand themselves on their potentials and help them to construct a passionate career for them. In the present scenario, Life Skills trainings are the catalyst which address all those concerns and which are widely adopted in corporates. Life skills are set of psycho social skills that enable an individual to develop their capacities and competencies and to deal with the challenges in various situations. It enhances leadership, adaptability, personal productivity, people skills, ethics, accountability, personal responsibility, self-direction, building and sustaining teamwork and managing creativity and diversity. Life skills promote equal opportunity and facilitate inclusive work culture and help establishing linkage between the employees and employers for development of the organization. Besides, Life skills are designed to help companies reduce employee health- risk behaviors that impact productivity and profitability. Life skills helps the employees to balance work life and personal life smoothly like by time management, goal setting, decision making etc.

Organization needs miscellany to become more innovative and open to change. Maximizing and exploiting on workplace diversity has become an important matter of management today. Now days emerged immense amount of challenges to manage a diverse work population. Managing diversity is not only acknowledging differences in people but it involves identifying the value of changes, combating perception, and promoting comprehensiveness.

So in this current scenario of the diverse force we can use Life Skills as a tool for managing the diversity which will lead to increase in productivity of both the organization as well as the employees

\section{NEED OF LIFE SKILlS IN CORPORATE SECTOR}

Performance appraisal in corporate sector is always related in terms of collection of skills and technical skills. The better the skills you can obtain and use, the more successful your performance will perform. In the last decade, high performance in corporate sector have devoted onto this rule quite well. Because of that, in the corporate world, the practice of talent based identification has been evolved in 
recruitment. One of the other trends that have emerged in recent years is practice of hiring employees based on the right balance of technical skills and Life Skills. In simple terms, technical skills - are those skills you need to complete a functional task. According to (UNESCO,2003) [3] "Life Skills are a group of cognitive, personal and interpersonal abilities that help people make informed decisions, solve problems, think critically and creatively, communicate effectively, build healthy relationships, empathize with others, and cope with and manage their lives in a healthy and productive manner." (UNESCO, 2003) [3]. In this context, Life skills can be termed as a set of personal skills and people skills for high performance. In other words, life skills are set of skills for teamwork, perform under pressure, get on well with others, communication skills and bounce back from an adverse situation. High performance in corporate sector recognized that it's not good enough to have the best with a technically equipped person, but Life skills are just as important as the technical skills. Now the sector doesn't want an employee with all the technical talent, yet lack the required soft skills or emotional intelligence, which we can term as Life Skills. Moreover, to build and develop a high performance, corporate need people who execute highly in both life skills and technical skills.

\section{A. Life Skills are Grouped into Two Categories}

- Personal skills, in which positive attitude, being honest, adapting to change, and managing your time, think, solve problems and make decisions

- People skills contribute in communicate with other people, team work skills which include getting along with the team, planning and implementing assigned tasks.

Life skills are also considered as transferable skills which is necessary in employability skills. It means how we are delivering ideas, views towards your performance. This article points on certain areas which need to be focused in corporate employee performance. Experience is considered as the primary agent for learning life skills. As you interact with others in the workplace, you use your transferable skills, observe the results and adjust your behavior. Learning and practicing life skills makes you valuable to an employer.

\section{SELF-MANAGEMENT}

It is persons' willpower, strong determination and sharp focus on their goals. These, when supplemented with sincere hard work, will help them realize their dream. One thing which needs to be noticed is that, a person with selfmanagement will always maintain inner tranquility and stillness no matter what may be the outer circumstances. They lock their inner self from outer notions. This is most required in corporate sector. This competence can be acquired by practicing self-regulation, self-motivation and understanding oneself. Those competencies can be acquired through selfawareness, which is termed as mother skill in Life Skills. It is this quality that gives them the required strength to get what they want. On the contrary, if one is internally weak, unstable, fearful, anxious etc. he/ she will never be able to achieve the goals even if hard work is put in. So, self-management plays a role in performance and life skills have a definite space in developing self-management skills.

\section{A. Stress Management}

Researches indicate that stress is the major cause for more than $80 \%$ of health problems. It mostly seen in corporate sector because of less job security, as job recession mostly effected in corporate, leads to develop high work pressure for impressing with their job performance. It is mainly one's attitude towards life that causes stress. Though we can't eliminate stress, we can learn the art of managing it. It needs to be addressed with coping strategies in which a person will be able to channelize his/ her stress in a positive way. In other words we can say that Life skills allow us to adopt certain mechanisms to manage our stress impulses and to inculcate stress tolerance.

\section{B. Relationship Management}

Everyone likes to be relating with others. Studies have proved that humans are moved by emotions more. Relationship is the key, as it plays a role in sharing emotions. For people who aspire to be successful in corporate, it becomes all the more important to have good relationship with others like team, boss, clients, etc. For a person to succeed, he/ she requires co-operation from others as they cannot succeed in life with their effort only. Here, Life Skills acts as a catalyst in building people skills where an employee can empathize with the customer needs, express the exact message to their team, superiors etc.

\section{Interpersonal Skills Management}

The Interpersonal skills are the key in developing rapport with others easily. The people who possess interpersonal skills know the art of building rapport. Then there is a genuine question arises why it is so? This is because people do business with people with the factor called trust. It becomes absolutely necessary to build rapport with others, be it an organization, business or corporate. Inter personal skill is one of the core skill in Life skills and it is considers as the major competency in developing people skill. In this, focus is stressing towards how to develop integrity, trust and honesty which are considered as the core element of ethics in corporate.

\section{Goal Setting}

Each individual has goals and it is nothing but the dreams and desires one has in life. Some people pursue it seriously by taking actions to make it happen and some will just let them remain as mere dreams But through Life Skills approach, a person will be able to develop short term and long term goals in respect to the factors such as specificity of goals, realistic goals and time bounded goals. It is based on the opportunities and challenges a person possess, which is essential in career development in corporate sector.

\section{E. Focus of Life Skills Training in Corporate Sector}

- Draw out the best in employees so they can make decisions that improve their performance.

- Helps people learn not only essential and practical things to lead a productive life, but they also support to create a sense of consistency and equilibrium. 
- A life skills training which helps people deal with challenges and change.

- It helps to find the best way to be more efficient and happy, and to overcome the challenges from their work

- Exposes to certain coping strategies to manage the stress

\section{CONCLUSION}

Training and development are the processes that attempt to provide an employee with the skills and information for their personal and professional development. In addition, training program is designed to help a person continue to make positive contribution in the form of good performance. Life Skills Training is a rapidly developing training program which helps the employee to take the right decisions, solve the problems and take care of their relationship and cope with the adversities. This training programme will be helpful for the employees to meet the daily challenge of managing professional and personal responsibilities in fact life skills training programme helps in establishing a good work life balance. Life Skills are playing an important role in determining a person's personality, they enable social competence, and they complement the technical skills, which are the practical requirements of any job. As such, life skills stand with equal importance alongside the technical skills, but they should not be distorted to cover-up a person's lack of proficiency in particular areas.

\section{ACKNOWLEDGMENT}

The authors would like to acknowledge Dr. A. Radhakrishnan Nair, Head of the Department, School of Life skills Education and Social Harmony, Rajiv Gandhi National Institute of Youth Development, Chennai for his support and guidance to develop this paper and Dr.P. Karthikeyan, Assistant Professor, Dept. of Management Studies, Kongu Engineering College for giving an opportunity to share our idea in a larger platform. The authors would like to acknowledge all the online sources and blogs for sharing the ideas for completing this paper. 